\title{
Modelling Sewage Sludge Composting in WWTP: Influence of Meteorological Conditions
}

\author{
Julie Bachelart, Cécile Hort, Vincent Platel, and Laurent Moynault
}

\begin{abstract}
This work presents the 2D modelling of a fermenting step during composting of a sewage sludge/bark mixture at the Aureilhan (France) WWTP. For this study the temporal evolution of the temperature has been studied because it is the composting key parameter, especially for achieving the compost sanitization. Thus, the modelling results have been compared with experimental results. Fermenting windrows are being subject to weather conditions, we took into account the temperature and humidity of the outside air in the model as boundary conditions. Results indicated that the model is consistent with windrow A but differed from the experimental results for windrow $B$. The weather conditions had a strong impact on the temperature profile during fermentation, especially the maximum temperature. Indeed, the maximum temperatures did not exceed $35^{\circ} \mathrm{C}$ for windrow $\mathrm{A}$ (winter) while they were around $50^{\circ} \mathrm{C}$ for windrow $\mathrm{B}$ (summer). On the other hand, the temperature rise in the windrows was faster for the experimental measurements than for the modelled results. Finally, the experimental and modelling results showed that the warmest temperatures were towards the center of the windrow. This trend is consistent with the suction aeration system.
\end{abstract}

Index Terms - Sludge composting, modelling, temperature, meteorological conditions.

\section{INTRODUCTION}

Municipal water treatment is traditionally carried out by biological way. This water treatment process produces a biological sludge. However, wastewater treatment plants (WWTPs) must provide a treatment process for their sludge. In this context, in order to recycle these biological wastes (rich in fertilizers [1]) in an environmentally friendly way, the WWTPs can turn to the composting process. Although the direct application of sludge to the soil can present certain health and environmental risks [2], composting provides a stabilised, hygienized and nutrient-rich substrate [3]. The risks associated with the presence of pathogenic micro-organisms initially contained in the sludge are then reduced.

Composting is a process of aerobic degradation of organic matter by micro-organism present in the waste. This process is exothermic, so it is accompanied by the release of heat which highly depends on the biodegradability of the substrate to be degraded. Thus, due to the heat released by biodegradation and the various heat losses resulting from

Manuscript received Febreary 9, 2020; revised October 23, 2020. This work was supported by the Communauté d'Agglomération Tarbes-Lourdes-Pyrénées, VEOLIA EAU and the LaTEP (laboratory of thermal engineering, energy and processes).

The authors are with the Universite de Pau \& Pays Adour, E2S UPPA, LaTEP, PAU, France (e-mail: julie.bachelart@univ-pau.fr, cecile.hort@univ-pau.fr, vincent.platel@univ-pau.fr, laurent.moynault@univ-pau.fr). operating conditions such as aeration, a temperature evolution is observed during composting. This evolution, impacting many parameters including microbial populations (in diversity and numbers) [4] and substrate biodegradation rates [5], allows the definition of two phases: fermentation and maturation. Contrary to the maturation step, fermentation is characterized by a strong temperature evolution. During, fermentation, the temperature of the substrate must be above $55^{\circ} \mathrm{C}$ for several days to achieve compost sanitization [6]. Fermentation is therefore a crucial step in the composting process that should be monitored.

The WWTP of Aureilhan (Véolia, France) performs compost with the sludge from waste water treatment. In order to improve the compost quality, temperature measurements of the windrows were taken during the step fermentation. This step fermentation was carried out in a semi-open shed so the impact of weather conditions was also studied.

In order to understand this phenomenon involved in composting numerous models over the last forty years were studied [7], [8]. Some models, specific to sewage sludge composting ([7], [9]-[12]), were shown the temperature evolution. However, these models have been validated at the pilot scale and not at the industrial scale. On the other hand, few studies [12] mentions the influence of weather conditions on temperature evolution during sludge composting. Indeed, Bailobrzewski [12] highlights a delay in the temperature increase during winter conditions.

To explain the temperature profiles obtained during the fermentation of the sludge/bark mixture at the Aureilhan WWTP, we have modelling this step. The model introduced below takes into consideration the real windrow dimensions (2D, industrial scale) as well as the meteorological conditions to which the windrows were subjected.

\section{METHOD}

\section{A. Industrial Site}

The Aureilhan WWTP performs the fermentation of the biological sludge/bark mixture in a semi-open shed to the outside (Fig. 1) with six fermentation spaces. The sludge/bark mixture has been placed on each space in such a way as to form a windrow with a volume and mass equal respectively to $100 \mathrm{~m}^{3}$ and 36 tons. The windrow dimensions are shown in Table 1. Each fermentation area was equipped with a $10 \mathrm{~cm}$ wide aeration duct positioned along the entire length of the windrow and centrally in relation to the windrow width (Fig. 1). This duct was covered with a perforated grid. At the duct outlet, a fan creates an air stream suction (30 minutes of suction followed by 30 minutes of shutdown). The average suction speed at the ventilation duct was $0.136 \mathrm{~m} / \mathrm{s}$. 

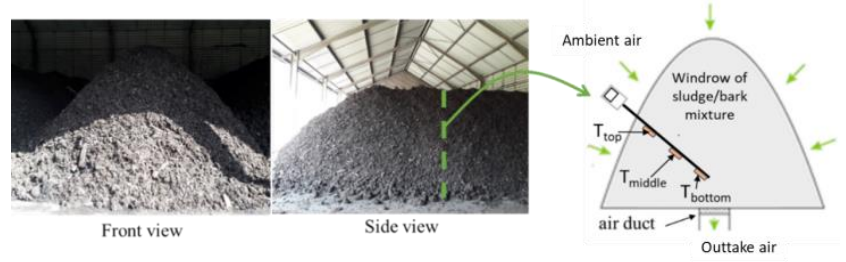

Fig. 1. Front view, windrow profile and position of thermocouples for temperature measurement

TABLE I: WINDROW AND AERATION DUCT DIMENSIONS

\begin{tabular}{lllll}
\hline \hline $\begin{array}{l}\text { Windrow } \\
\text { length } \\
(\mathrm{m})\end{array}$ & $\begin{array}{l}\text { Windrow } \\
\text { width } \\
(\mathrm{m})\end{array}$ & $\begin{array}{l}\text { Windrow } \\
\text { height } \\
(\mathrm{m})\end{array}$ & $\begin{array}{l}\text { Ventilation } \\
\text { duct length } \\
(\mathrm{m})\end{array}$ & $\begin{array}{l}\text { Ventilation } \\
\text { duct width } \\
(\mathrm{m})\end{array}$ \\
\hline 12.0 & 6.2 & 3.0 & 12.0 & 0.1 \\
\hline \hline
\end{tabular}

\section{B. Materials and Experimental Temperature Measurement}

The composting mixture studied was composed of biological sludge (secondary sludge) and bark in the following theoretical proportions: 1 volume of sludge for 3 volumes of bark. The bark acts as a structuring agent, it was recovered at the end of the composting process to be mixed again with the sludge before the step fermentation. For this reason, and considering that their biodegradation rates are lower than those of sludge (70 to 10 times lower, [5]), we have considered bark to be inert. The dry matter fractions of the sludge and the sludge/bark mixture were experimentally measured by drying to constant mass in a furnace at $105^{\circ} \mathrm{C}$ (Table II). The fraction of organic matter contained in the dry sludge (Table II) was estimated by measuring the volatile matter (calcination at $550^{\circ} \mathrm{C}$ for 2 hours).

TABLE II: RAW MATERIALS CHARACTERISTICS MEASURED EXPERIMENTALLY

\begin{tabular}{|c|c|c|c|}
\hline Raw material & $\begin{array}{l}\text { Dry matter } \\
(\%)\end{array}$ & Volatile solid (\%) & $\begin{array}{l}\text { Bulk density } \\
\left.\left(\mathrm{kg} \cdot \mathrm{m}^{-3}\right) \mathrm{kg} \cdot \mathrm{m}^{-3}\right)\end{array}$ \\
\hline Sewage sludge & $\begin{array}{l}16.885 \pm \\
0.006\end{array}$ & $77.90 \pm 0.04$ & \\
\hline $\begin{array}{l}\text { Substrate } \\
\text { (sludge/bark } \\
\text { mixture) }\end{array}$ & $\begin{array}{l}38.00 \pm \\
0.01\end{array}$ & 11.6 (calculated) & $365.8 \pm 0.3$ \\
\hline
\end{tabular}

Temperature measurements were taken on two windrows in fermentation. Windrow A was followed during winter weather conditions (February 2018) while windrow B was followed during summer weather conditions (July 2018). To measure the temperature evolution during fermentation, a pole equipped with three thermocouples and a recorder was installed through each of the two windrows as shown in the Fig. 1. In this way, the temperature could be measured as a function of the windrow depth.

\section{Numerical Model}

Three types of kinetics are commonly used in the literature to model the different substrate biodegradation processes [7], [8]: 1) first-order kinetics; 2) Monod's law kinetics; 3) empirical relation. As the objective of this work was not to follow the evolution of microbial populations or to detail the numerous biological mechanisms as proposed by Sole-Maury [13], we have excluded the use of a Monod's law to model biodegradation kinetics. Similarly, since we could not experimentally measure the biodegradation kinetics of the substrate (empirical relationship), we have oriented ourselves towards first-order kinetics based on the Haug's model [5]. Indeed, first-order kinetics were observed experimentally in the case of co-composting of sludge with a mixture of wood chips, wheat straw and leaves [14]. Moreover, Haug's kinetic [5] has already been used in several models ([10], [11], [15]), two of which have applied it to the co-composting of sludge ([10], [11]). This kinetic model distinguishes two types of compounds: slowly (SB) and fast (FB) biodegradable compounds. It also allows taking into account the impact of several factors such as porosity, temperature, moisture content and $\mathrm{O} 2$ availability. However, as specified by Zhou [9], Haug's model does not consider the influence of the type of microbial population on the biodegradation kinetic constant. Thus, Zhou [9] has differentiated in this kinetic model (based on the Haug's model), the role of mesophilic and thermophilic microorganisms on the biodegradation kinetic constant.

Thereby, using a first-order kinetics according to Haug's model [6], the biodegradation kinetics of the compounds FB and SB are given by:

$$
\frac{d m_{i}^{V}}{d t}=-k_{i} \cdot m_{i}^{V}
$$

$i$ refers to slowly (SB) or fast (FB) biodegradable compounds. $m_{i}^{V}$ is the masse of $i$ per windrow volume unity, $k_{i}$ the biodegradation rates of fast and slowly biodegradable compounds, calculated by:

$$
k_{i}=k_{i, T} k_{H 2 O} k_{\varepsilon_{g}} k_{O 2}
$$

$k_{i, T}$ are kinetic constants calculated according to the model proposed by Zhou [9]. The coefficients $k_{H 2 O}, k_{O 2}$ and $k_{\varepsilon_{g}}$ are the correction factors for humidity effect, gas phase volume fraction and oxygen availability respectively, according to the Haug's model [5].

The mass balances used in this model was derived from the Pujol [7], based on several assumptions:

- The flow velocity of the liquid phase is null (hypothesis is justified in our case since there is no leachate recovery from the composting process).

- The only gaseous species considered in the model are $\mathrm{O}_{2}$, $\mathrm{CO}_{2}, \mathrm{~N}_{2}$ and $\mathrm{H}_{2} \mathrm{O}$.

- The liquid phase consists only of water.

In the Pujol model [7] appears $\dot{m}_{H_{2} O \text {,gl }}$ which is a mass flow rate per unit volume representing the mass transfer for water between the gas and liquid phases. $\dot{m}_{\mathrm{H}_{2} \mathrm{O}, \mathrm{gl}}$ is given by the following equation [7]:

$$
\dot{m}_{\mathrm{H}_{2} \mathrm{O}, \mathrm{gl}}=\sigma \varepsilon_{g} \rho_{g}\left(x_{\mathrm{H}_{2} \mathrm{O}, \mathrm{g}, \mathrm{eq}}-x_{\mathrm{H}_{2} \mathrm{O}, \mathrm{g}}\right)
$$

$\sigma$ is an exchange coefficient, $\varepsilon_{g}$ the volume fraction of gas, $\rho_{g}$ the density of the gas phase, $x_{\mathrm{H}_{2} \mathrm{O}, \mathrm{g}}$ the mass fraction of water in the gas phase and $x_{\mathrm{H}_{2} \mathrm{O}, \mathrm{g} \text {,eq }}$ is the mass fraction of water at equilibrium.

The production terms ( $R_{\mathrm{H}_{2} \mathrm{O}}^{V}$ and $R_{\mathrm{CO}_{2}}^{V}$ ) and the consumption term $R_{\mathrm{O}_{2}}^{V}$ have been estimated based on organic matter consumption [15]: 


$$
\begin{aligned}
& R_{i}^{V}= \pm Y_{i} \times \frac{\partial m_{M O}^{V}}{\partial \mathrm{t}} \\
& Y_{i}=\frac{\operatorname{Coef}_{i} \times M_{i}}{M_{M O}}
\end{aligned}
$$

Here, $i=\mathrm{O}_{2}, \mathrm{CO}_{2}$ or $\mathrm{H}_{2} \mathrm{O}$. The "+" sign is used for $\mathrm{O}_{2}$ while the "-" sign is used for $\mathrm{CO}_{2}$ and $\mathrm{H}_{2} \mathrm{O} . Y_{i}$ is determined in regards to the biodegradation reaction of the organic matter (equation (6)). $M_{M O}$ and $M_{i}$ are respectively the molar masses of the organic matter and the specie $i$. Coef $f_{i}$ is the stoichiometric coefficient associated with each gaseous specie $i$ (equation (6)). For sewage sludge of the formula $\mathrm{C}_{5} \mathrm{H}_{7} \mathrm{O}_{2} \mathrm{~N}$ [16], the biodegradation reaction is described by:

$$
\mathrm{C}_{5} \mathrm{H}_{7} \mathrm{O}_{2} \mathrm{~N}+5 \mathrm{O}_{2} \rightarrow 5 \mathrm{CO}_{2}+2 \mathrm{H}_{2} \mathrm{O}+\mathrm{NH}_{3}
$$

We assumed that liquid phase velocity was null and that the windrow is homogeneous and isotropic. The conservation of momentum in porous media for incompressible two-phase flows can be described by a generalized Darcy's law [17].

$$
\overrightarrow{u_{g}}=-\frac{\kappa_{g}}{\eta_{g}}\left(\vec{\nabla} P_{g}-\rho_{g} \vec{g}\right)
$$

where $\kappa_{g}$ is the gas phase permeability, $\eta_{g}$ the dynamic viscosity, $P_{g}$ the pressure of the gas phase and $\vec{g}$ the gravity field.

The main assumptions used to heat balance equation sheet are:

- local thermal equilibrium at the interfaces;

- mass thermal capacity of the solid phase doesn't depend on its composition.

As for mass conservation, the heat balance equation was derived from Pujol [7]:

$$
\begin{array}{r}
\left(\varepsilon_{g} \rho_{g} \sum_{i} x_{i, g} C_{P, i g}+\varepsilon_{l} \rho_{l} C_{P, l}+\varepsilon_{s} \rho_{s} C_{P, S}\right) \frac{\partial T}{\partial \mathrm{t}}+ \\
\varepsilon_{g} \rho_{g} C_{P, g} u_{g} \cdot \vec{\nabla} \mathrm{T}=\Delta .\left(\lambda^{*} \nabla T\right)-\dot{m}_{H_{2} O, g l} \Delta H_{v a p}+R_{T, b i o}^{v}
\end{array}
$$

where $T$ is the windrow temperature, $\rho_{l}$ the density of liquid phase, $C_{P, l}$ the specific heat capacity of the liquid phase, $C_{P, S}$ the specific heat capacity of the solid phase and $C_{P, i g}$ the specific heat capacity of gaseous component $i\left(\mathrm{O}_{2}, \mathrm{~N}_{2}, \mathrm{CO}_{2}\right.$, $\mathrm{H}_{2} \mathrm{O}$ ). $R_{T, \text { bio }}^{v}$ is the amount of heat produced by the biodegradation reaction. It is estimated by the heat released by organic matter combustion ([5], $[9,[10])$ :

$$
R_{T, b i o}=-H_{r x} \frac{\partial m_{M O}}{\partial \mathrm{t}}
$$

where $H_{r x}$ is the heat of combustion for solid volatile.

The temperature and relative air humidity at the surface of the windrow were fixed using meteorological data for the city of Aureilhan, provided by the meteoblue website [18]. The time step of the meteoblue data is one hour, thus, a linear regression is performed to obtain the intermediate points.

The composition of the gas phase in contact with the surface of the windrow was determined using air data from Allaby [19]. The mass fraction of water in the air was

\begin{tabular}{|c|c|c|c|}
\hline Coefficients & Value & Units & References \\
\hline$k_{L B, 20}$ & $4,6.10^{-8}$ & $s^{-1}$ & Haug [5] \\
\hline$k_{R B, 20}$ & $1,7 \cdot 10^{-7}$ & $s^{-1}$ & Haug [5] \\
\hline$D_{O_{2}, g}$ & $\begin{array}{l}D_{O_{2}, g} \\
=1,24 \cdot 10^{-7} \times T \\
-1,63 \cdot 10^{-5}\end{array}$ & $m^{2} \cdot s^{-1}$ & $\begin{array}{l}\text { adapted } \\
\text { from [20] }\end{array}$ \\
\hline$D_{N_{2}, g}$ & $\begin{array}{l}D_{N_{2}, g} \\
=1,20 \cdot 10^{-7} \times T \\
-1,55 \cdot 10^{-5}\end{array}$ & $m^{2} \cdot s^{-1}$ & $\begin{array}{l}\text { adapted } \\
\text { from [20] }\end{array}$ \\
\hline$D_{\mathrm{CO}_{2}, \mathrm{~g}}$ & $\begin{array}{l}\mathrm{D}_{\mathrm{CO}_{2}, \mathrm{~g}} \\
=1,21 \cdot 10^{-7} \times T \\
-1,67 \cdot 10^{-5}\end{array}$ & $m^{2} \cdot s^{-1}$ & $\begin{array}{l}\text { adapted } \\
\text { from [20] }\end{array}$ \\
\hline$D_{H_{2 O}, g}$ & $\begin{array}{l}D_{H_{2 O}, g} \\
=1,44 \cdot 10^{-7} \times T \\
-2,15 \cdot 10^{-5}\end{array}$ & $m^{2} \cdot s^{-1}$ & $\begin{array}{l}\text { adapted } \\
\text { from [20] }\end{array}$ \\
\hline$\rho_{l}$ & 1000 & $\mathrm{~kg} \cdot \mathrm{m}^{-3}$ & {$[21]$} \\
\hline$\tau_{t, g}$ & 10 & & estimated \\
\hline$\sigma$ & 0.001 & $s^{-1}$ & fixed \\
\hline$\kappa_{g}$ & $1,2 \times 10^{-7}$ & $m^{2}$ & {$[22]$} \\
\hline$\eta_{g}$ & $\begin{array}{l}\eta_{g} \\
=4,63 \cdot 10^{-8} \times(T \\
-273,15)+1,72 \cdot 10^{-5} \\
C_{p, s}\end{array}$ & Pa.s & {$[21]$} \\
\hline$C_{p, s}$ & $\begin{array}{l}=x_{M V, \text { subs }} \times C_{p, B S}+(1 \\
\left.-x_{M V, \text { subs }}\right) \times C_{p, E C S} \\
\quad C_{p, B S}\end{array}$ & J. $\mathrm{kg}^{-1} \cdot K^{-1}$ & estimated \\
\hline$C_{p, D S}$ & $\begin{array}{l}=1040+2,72 \times(T \\
-273,15)\end{array}$ & J. $\mathrm{kg}^{-1} \cdot K^{-1}$ & [23] \\
\hline$C_{p, \text { Dbark }}$ & $C_{p, E C S}=2090$ & $J \cdot \mathrm{kg}^{-1} \cdot \mathrm{K}^{-1}$ & $\begin{array}{l}\text { pine wood } \\
{[24]}\end{array}$ \\
\hline$\lambda^{*}$ & $\begin{array}{l}\lambda^{*} \\
=(0,0035 \\
\times(T-273,15) \\
+0,0605)+(0,0004 \\
\times(T-273,15) \\
+0,0403) \times\left(\frac{65-H}{15}\right)\end{array}$ & $W \cdot m^{-1} \cdot{ }^{\circ} C^{-1}$ & $\begin{array}{l}\text { adapted } \\
\text { from [22] }\end{array}$ \\
\hline$H_{r x}$ & $23.10^{6}$ & J. $\mathrm{kg}^{-1}$ de $M V$ & [25] \\
\hline
\end{tabular}
calculated from the relative humidity, temperature and pressure conditions.

The average of the initial temperatures measured by the three probes was used as the initial windrow temperature. The initial composition of the gas phase in the windrow was assumed to be the same as the one of ambient air at $\mathrm{t}=0 \mathrm{~s}$.

The mass heat capacities $\left(C_{p, l}, C_{P, i g}\right)$ and the latent heat of evaporation $\left(\Delta H_{v a p}\right)$ were taken from ProSimPlus software. The other data used in the numerical model are presented in Table 3. $D_{\mathrm{O}_{2}, \mathrm{~g}}, D_{\mathrm{N}_{2}, \mathrm{~g}}, D_{\mathrm{CO}_{2}, \mathrm{~g}}$ and $D_{\mathrm{H}_{2}, \mathrm{~g}}$ are respectively the diffusion coefficient of $\mathrm{O}_{2}, \mathrm{~N}_{2}, \mathrm{CO}_{2}$, et $\mathrm{H}_{2} \mathrm{O} . \tau_{t, g}$ is the tortuosity. $x_{M V, \text { subs }}$ is the mass fraction of organic matter contained in the substrate.

The model was solved using FreeFEM++ software (Finite Element Method, version 4.2.1).

\section{RESUlts}

The numerical simulation of the model provides the temperature field in the windrow, thus at the position of the three thermocouples used for the experimental measurements (top, middle and bottom, see Fig. 1). The results are shown in the Fig. 2 for windrow A and in the Fig. 3 for windrow B.

Fig. 2 shows temperature profiles obtained by the model seems to fit the experimental measurements. Indeed, on graphs (a) and (b), a temperature rise has been observed during the first days, due to the organic matter biodegradation by micro-organisms (exothermic reaction). The maximum temperatures were almost equals for both the simulation and the experimental results (close to $34^{\circ} \mathrm{C}$ for Tbottom, $27^{\circ} \mathrm{C}$ for 
Tmiddle and $21^{\circ} \mathrm{C}$ for Ttop). After this first phase of temperature increase, a temperature decrease was observed during the last days of fermentation for both simulation and experimental results. At the end of fermentation, the temperature increase is greater for experimental measurements (more than $10^{\circ} \mathrm{C}$ from 15 to 21 days) than for the simulation results (less than $5^{\circ} \mathrm{C}$ from 15 to 21 days). In addition to the impact of external temperatures, this temperature increase can be related to biological activity at the end of fermentation. This means that the windrow A was not stabilized at the end of fermentation.

The global temperature profile obtained by the numerical resolution of the model was similar to the experimental measurements. However, the first temperature increase was twice as fast for the experimental results as for the simulation results. Several hours to a few days are needed to form the windrow. The probes are then installed, which may partly explained these results: biological activity has therefore already started before the temperatures recording. These differences can also be explained by the kinetic model. An improvement or a change in this model can be envisaged later.

The same trend was observed for the experimental and simulation results with respect to the influence of depth. In both cases, the warmest temperatures were observed towards the centre of the windrow, while the coldest temperatures were observed at the windrow's areas close to the surface. This temperature difference as a function of the windrow's depth can reach $10^{\circ} \mathrm{C}$ between two successive probes (Figure 2 ). These results seem to be consistent: the windrow was aerated by an exhaust ventilation system and was in contact with the outside environment. Thus, the cold air (winter conditions) passing through the windrow first cools the areas close to the outside environment. This air is generally not saturated, so the heat loss due to water vaporisation in the windrow is greater in areas close to the outdoor environment. Then, the relative air humidity is higher in the core of the windrow.
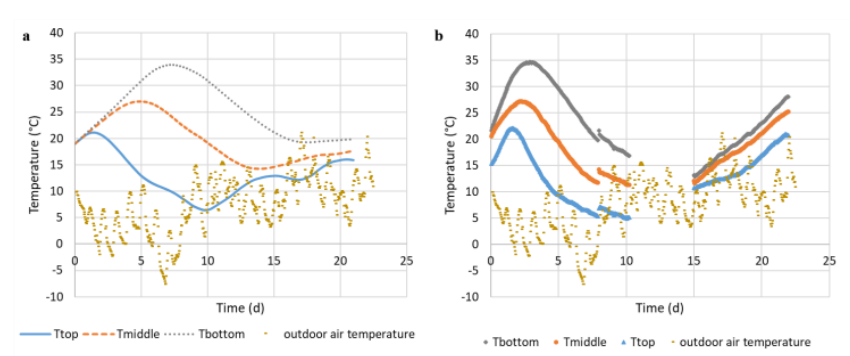

Fig. 2. Temperature evolution obtained from the simulations (a) and from experimental measurements (b) for windrow A.

We previously observed that the maximum temperatures were reached towards the bottom of the windrow (Tbottom). However, the temperatures did not exceed $35^{\circ} \mathrm{C}$. To achieve compost hygienization, the temperature of the composted mixture must exceed $55^{\circ} \mathrm{C}$ for several days [6]. We can therefore consider that windrow A was not able to achieve sanitization allowing the elimination of pathogens. During fermentation, the very low temperatures can be due to bad operating conditions, such as a low sludge/structuring agent ratio or high heat loss due to aeration. Indeed, if too much bark is added to the sludge, the biodegradable organic matter is not present in sufficient quantity to reach high temperatures while too much aeration during winter conditions tends to cool the windrow.
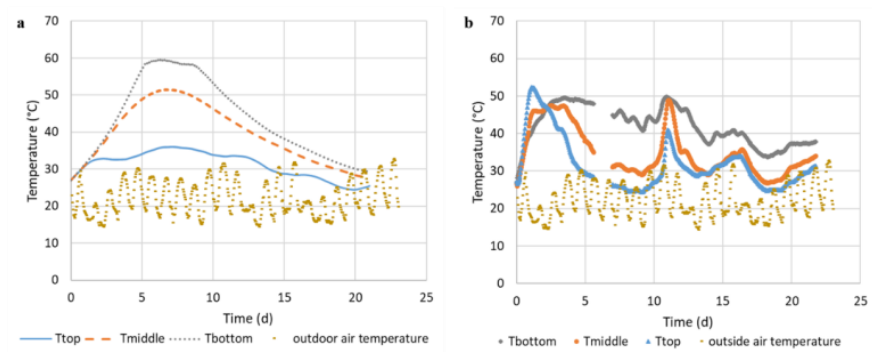

Fig. 3. Temperature evolution obtained from the simulation (a) and from experimental measurements (b) for windrow $\mathrm{B}$.

From Fig. 3, we can see that the temperatures obtained from the simulations do not follow the experimental results obtained for windrow B. Indeed, they indicate a single temperature increase during fermentation. From experimental measurements, we observe two high temperature values, one at the beginning of fermentation (from 0 to 2 days), and the other one in the middle of fermentation (from 9 to 11 days). The first temperature increase is typical of a fast biodegradation of compounds by microorganisms. The second temperature increase seems independent of weather conditions, it is thus probably caused by a resuming of the biological activity. Therefore, the operating conditions that were no longer optimal to maintain a biological activity after the first increase of temperature became briefly favourable to the microorganisms around the ninth day of fermentation. In addition, as observed for windrow $\mathrm{A}$, the biodegradation kinetics were slower for the simulation results compared to the experimental measurements. A modification of the kinetic model could be considered in order to obtain matching results with the experimental values.

Experimental results (graph (b), Fig. 3) show that apart from areas where biological activity is the most intense ( 0 to 4 days and 9 to 13 days), the measured temperatures in the windrow seem to be dependent on the outside temperature evolution. In fact, the maximum daily temperatures seem to follow the evolution of temperatures measured for the three probes. The ambient temperature has therefore a significant impact on the measured temperature profiles. For the simulation results, the impact of outside temperatures is less obvious. Only the simulated temperatures close to the outside environment $\left(\mathrm{T}_{\text {top }}\right)$ show a direct influence of external temperatures from the tenth day of fermentation. In order to observe the real influence of weather conditions on the windrow temperatures, we used the same input data for both windrows $\mathrm{A}$ and $\mathrm{B}$. Only the following parameters were changed in the simulation: the temperature and the relative humidity of the outside air and the initial temperature of the windrows. By comparing Fig. 2 and Fig. 3 (graphs (a)) it appears that the temperature profiles are greatly influenced by the weather conditions. Indeed, the maximum temperature calculated with the model was about $35^{\circ} \mathrm{C}$ for windrow $\mathrm{A}$ compared to $60^{\circ} \mathrm{C}$ for windrow B. Thus, a high ambient temperature leads to high maximum temperatures in the windrow. 


\section{CONCLUSIONS}

In this work, a 2D model was proposed to monitor temperature changes at three different depths in the windrow. The simulation results were then compared to experimental data for two windrows under different weather conditions (summer and winter). From results we obtained, the following conclusions can be drawn: 1) the model produced results close to experimental measurements for windrow A. On the other hand, the simulation results differed from experimental measurements for windrow $\mathrm{B}$; 2) outside temperatures affected the temperature profiles for the simulation and the experimental results; 3) high outdoor temperature is correlated with high maximum temperatures in the windrow; 4) a delay in biodegradation kinetics for the simulation results compared to the experimental data was observed for both windrows; 5) due to the used aeration system, the highest temperatures in the windrow were towards the centre.

\section{CONFLICT OF INTEREST}

The authors declare no conflict of interest.

\section{AUTHOR CONTRIBUTIONS}

J. Bachelart conducted the research and experimental measurements. J. Bachelart, C. Hort and V. Platel analyzed the data and wrote the paper. L. Moynault contributed to experimental measurements. All authors had approved the final version.

\section{REFERENCES}

[1] H. Cheng, W. Xu, J. Liu, Q. Zhao, Y. He, and G. Chen, "Application of composted sewage sludge (CSS) as a soil amendment for turfgrass growth," Ecological Engineering, vol. 29, no. 1, pp. 96-104, 2007, doi: 10.1016/j.ecoleng.2006.08.005

[2] T. Hernández, G. Masciandaro, J. I. Moreno, and C. García, "Changes in organic matter composition during composting of two digested sewage sludges," Waste Management, vol. 26, no. 12, pp. 1370-1376, 2006, doi: 10.1016/j.wasman.2005.10.006.

[3] T. Gląb et al., "Fertilization effects of compost produced from maize, sewage sludge and biochar on soil water retention and chemical properties," Soil and Tillage Research, vol. 197, p. 104493, 2020, doi: 10.1016/j.still.2019.104493.

[4] E. Chinakwe et al., "Effect of Temperature Changes on the Bacterial and Fungal Succession Patterns during Composting of Some Organic Wastes in Greenhouse," Journal of Advances in Microbiology, pp. 1-10, 2019, doi: 10.9734/jamb/2019/v15i130075.

[5] R. T. Haug, The Practical Handbook of Compost Engineering, 1st Edition. CRC Press, 1993.

[6] S. Dumontet, H. Dinel, and S. B. Baloda, "Pathogen Reduction in Sewage Sludge by Composting and Other Biological Treatments: A Review," Biological Agriculture \& Horticulture, vol. 16, no. 4, pp. 409-430, 1999, doi: 10.1080/01448765.1999.9755243.

[7] A. Pujol, "Modélisation du procédé de compostage - Impact du phénomène du séchage," Université de Toulouse, 2012.

[8] I. G. Mason, "Mathematical modelling of the composting process: A review," Waste Management, vol. 26, no. 1, pp. 3-21, 2006, doi: 10.1016/j.wasman.2005.01.021.

[9] H.-B. Zhou et al., "Simulation of water removal process and optimization of aeration strategy in sewage sludge composting," Bioresource Technology, vol. 171, pp. 452-460, 2014, doi: 10.1016/j.biortech.2014.07.006.

[10] J. Zhang et al., "Simulation of substrate degradation in composting of sewage sludge," Waste Management, vol. 30, no. 10, pp. 1931-1938, 2010, doi: 10.1016/j.wasman.2010.04.004.
[11] D. S. Kim, J. O. Kim, and J. J. Lee, "Aerobic composting performance and simulation of mixed sludges," Bioprocess Engineering, vol. 22, no. 6, pp. 533-537, 2000.

[12] I. Białobrzewski, M. Mikš-Krajnik, J. Dach, M. Markowski, W Czekała, and K. Gluchowska, "Model of the sewage sludge-straw composting process integrating different heat generation capacities of mesophilic and thermophilic microorganisms," Waste Management, vol. 43, pp. 72-83, 2015, doi: 10.1016/j.wasman.2015.05.036.

[13] F. Sole-Mauri, J. Illa, A. Magrí, F. X. Prenafeta-Boldú, and X. Flotats, "An integrated biochemical and physical model for the composting process," Bioresource Technology, vol. 98, no. 17, pp. 3278-3293, 2007, doi: 10.1016/j.biortech.2006.07.012

[14] D. Kulikowska, "Kinetics of organic matter removal and humification progress during sewage sludge composting," Waste Management, vol. 49, no. Supplement C, pp. 196-203, 2016, doi: 10.1016/j.wasman.2016.01.005.

[15] I. Petric and V. Selimbašić, "Development and validation of mathematical model for aerobic composting process," Chemical Engineering Journal, vol. 139, no. 2, pp. 304-317, 2008, doi 10.1016/j.cej.2007.08.017.

[16] M. Henze, P. Harremoes, J. C. Jansen, and E. Arvin, Wastewater Treatment: Biological and Chemical Processes, Springer Science \& Business Media, 2001.

[17] D. Chenu, "Modélisation des transferts réactifs de masse et de chaleur dans les installations de stockage de déchets ménagers: Application aux installations de type bioréacteur," Institut National Polytechnique de Toulouse, 2007

[18] (2020). Télécharger données historiques Aureilhan. Meteoblue [Online]. Available: http://www.meteoblue.com/

[19] M. Allaby, Atmosphere: A Scientific History of Air, Weather, and Climate, Infobase Publishing, 2009.

[20] E. L. Cussler, Diffusion: Mass Transfer in Fluid Systems, Cambridge University Press, 1997.

[21] R. H. Perry and D. W. Green, Perry's Chemical Engineers' Handbook, 7 edition, New York: McGraw-Hill Professional, 1997.

[22] J. Huet, C. Druilhe, and G. Debenest, "Study of thermal conductivity in organic solid wastes before composting," présenté à 8th International Conference ORBIT2012, 12 June 2012 - 15 June 2012, Rennes, France, 2012.

[23] W.-Y. Deng et al., "Measurement and simulation of the contact drying of sewage sludge in a Nara-type paddle dryer," Chemical Engineering Science, vol. 64, no. 24, pp. 5117-5124, 2009, doi: 10.1016/j.ces.2009.08.015.

[24] P. A. Miller and N. L. Clesceri, Waste Sites as Biological Reactors: Characterization and Modeling, 1 edition. Boca Raton, Fla: CRC Press, 2002.

[25] E. Guibelin, "Caractéristiques et traitements des boues d'épuration," Techniques de l'Ingénieur, avr. 10, 2014.

Copyright $(92020$ by the authors. This is an open access article distributed under the Creative Commons Attribution License which permits unrestricted use, distribution, and reproduction in any medium, provided the original work is properly cited (CC BY 4.0).

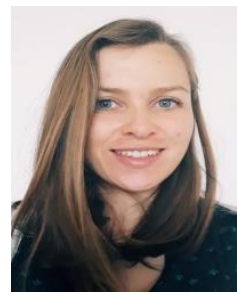

Julie Bachelart is a $\mathrm{PhD}$ student in process engineering at the Laboratory of Thermal engineering, Energy and Processes (LaTEP), part of the University of Pau and the Adour region (UPPA) In 2013, she graduated with process engineering degree at the Higher National School of Industrial Technology Engineering (ENSGTI), in Pau, France. Between 2014 and 2017 she participated on research projects dealing with air treatment and biolixiviation.

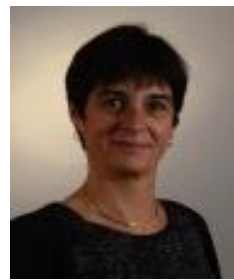

Cécile Hort is a senior associate professor at LaTEP of UPPA. She is an expert in biological processes and in the coupling of processes (i.e adsorption/biofiltration) applied to the treatment of gaseous phases. 